\title{
Multiple biomarkers response in Nile tilapia, Oreochromis niloticus (L.) exposed to sublethal concentrations of hexavalent chromium
}

\author{
Iman M. Elsaeidy ${ }^{1}$; Hanaa E. Assem ${ }^{1}$; Gamal M. F. Edrees ${ }^{2}$ and \\ Azza S. Khalifa ${ }^{1}$ \\ 1- Fish Physiology Department, National Institute of Oceanography and Fisheries, \\ Alexandria. Egypt. \\ 2- Department of Zoology, Faculty of Science. Mansoura University, Egypt.
}

\section{ABSTRACT}

The effect of two sublethal concentrations $(15,30 \mathrm{mg} / \mathrm{l})$ of $\mathrm{Cr}^{6+}$ on Nile tilapia, Oreochromis niloticus has been studied using some hematological and biochemical parameters aiming to evaluate their possible potential use as biomarkers of stress and/or defense. Hemoglobin content decreased throughout the experiment period, compared to the control. Moreover, the plasma glucose content and uric acid increased in both $\mathrm{Cr}^{6+}$ concentrations. Plasma urea decreased during the first $24 \mathrm{hr}$ of exposure, then it increased, thereafter decreased and finally fish recovered. Also, the brain $\mathrm{AChE}$ of the lower concentration showed significant fluctuations starting with inhibition of the enzyme then activation and final tendency to recover, while the higher concentration showed a significant increase throughout the whole experimental period with no sign of recovery. Plasma AChE has been inhibited and no sign of recovery was detected. Gill $\mathrm{Na}^{+}-\mathrm{K}^{+}$-ATPase specific activity remained unchanged in fish exposed to both $\mathrm{Cr}^{6+}$ concentrations during the whole experimental time. Liver metallothionein (MT) content increased in both fish treated with $\mathrm{Cr}^{6+}$ concentrations.

The present results indicated that blood $\mathrm{Hb}$, plasma glucose followed by brain AChE are more sensitive indicators of general stress. However, MT, to a lesser extent, may be considered a valuable biomarker of defense. Finally, plasma AChE may also be considered as a biomarker of defense.

\section{INTRODUCTION}

River Nile has been considered the main freshwater resource for the country, as it fulfills nearly all the demands for drinking water, farming activities, and industry. During its flow through Egypt, the river Nile gets various non-point and point source releases (Osman et al., 2010). The intentional discharge and occasional release of unfavorable chemical compounds into the River have the capability to disturb the structure and function of the natural ecosystems.

Contamination by heavy metals has turned into an ecological and general health risk on the grounds that the concentrations discharged into the environment from industrial procedures regularly surpass admissible levels. Because of their bioaccumulative and non-biodegradable characteristics, heavy metals make up a core group of aquatic toxins (Vutukuru et al., 2007). Their high danger even in low fixations can create total harmful impacts in a wide assortment of fish and other aquatic organisms.

Chromium is extensively used in several industries, and many factories discharge their untreated wastes into the aquatic environment (Gheju, 2011). Mishra and Mohanty (2009) found that $\mathrm{Cr}^{6+}$, present in water as $\mathrm{HCrO}_{4}^{-} ; \mathrm{HCr}_{2} \mathrm{O}_{7}^{-} ; \mathrm{Cr}_{2} \mathrm{O}_{7}{ }^{2-}$, and $\mathrm{CrO}_{4}^{2}$, has been correlated with unfavorable biological effects at all the biological organization levels. Li et al., ( 2010) reported that hexavalent chromium is considered 
the toxic chromium form because it can easily cross cell membranes and become reduced to the trivalent form which complexes with intracellular macromolecules, including genetic material, and ultimately becomes responsible for the toxic and mutagenic capacities of chromium. The use of hexavalent chromium in the present study was due to its detection in most Egyptian freshwater bodies. $\mathrm{Cr}^{6+}$ concentration was very high in the sediments along the River Nile. However, the concentration in water was high during summer months and only in Rosetta branch, in which it causes massive mortalities in the fish populations (Masoud et al., 2005; Abdel- sabour, 2007; Osman, and Kloas, 2010.; Abdallah, 2014; Ibrahim and Omar, 2013 and Zaki et al., 2014). Dautremepuits et al., (2004) stated that fish are largely being used for the assessment of the aquatic environment's quality and so it may serve as bioindicators of environmental pollution.

The potency of using biomarkers to control either environmental status or the health of the organisms inhabiting polluted ecosystems has gotten a great concern lately. In a polluted environment, the toxic chemicals taken up by the organisms will initially produce alterations at the molecular level (structure and function of proteins, enzyme-substrate interactions, metabolites, nucleic acids, etc.). This will cause dysfunction of the cells and tissues and consequently reduction in the growth, the reproduction or the survival capability (Vaseem and Banerjee, 2012). The use of biomarkers could represent an appropriate way to correlate data related to the concentrations of chemical pollutants in aquatic organisms with the change of their physiology. Such an approach could be a highly informative, low cost, a complement to the chemical monitoring program developed in the past years, so that, the biomarkers could provide an early warning for long-term pollutant effects.

The selection of fish as a model in eco-toxicological studies could be valuable as they might serve as a very sensitive bioindicator of aquatic contamination. Nile tilapia, Oreochromis niloticus L., is one of the most important fish species in Egypt. It represented the species of choice due to its high growth rate, tolerance to environmental stress, ease of reproduction, and high market demand (El-Sayed 2006).

The biochemical parameters that evaluate mammalian health are not advanced for use in fisheries assessment so that enhanced diagnostic methods are of a great necessity. Once reference values are established, hematological and biochemical analysis can give intrinsic diagnostic data.

Since fish blood analysis is used in diagnosis, assessment of its physiological state and the effect of hazardous substances, (Assem et al., 2013), the objective of the present study was to investigate the potential use of some hematological and biochemical changes in Nile tilapia, (O. niloticus L.). The evaluation of fish responses to two sublethal concentrations of hexavalent chromium was studied to give information concerning not only the chemical actions but also the potential consequences of exposure and could serve as more effective tool in ecological monitoring system.

\section{MATERIALS AND METHODS}

\section{Preparation of the fish for experiments}

Nile tilapia, Oreochromis niloticus fingerlings ranging in length from 6.0 to 8.0 $\mathrm{cm}$ and weighing 10-15 g were obtained from a commercial hatchery and stocked in 9 glass aquaria of $70.5 \mathrm{~L}(61 \times 34 \times 34 \mathrm{~cm})$ filled with dechlorinated tap water supplied with steady aeration. The aquaria were divided into 3 groups (three test aquaria per each group); each group was assigned to one treatment. The temperature was kept at 
$\left(24 \pm 2{ }^{\circ} \mathrm{C}\right)$, hardness $5.2 \mathrm{mg} / 1$ as $\mathrm{CaCO}_{3} ; \mathrm{Ca}^{2+}$ 0.045-0.069 mM/l; $\mathrm{Na}^{+} 0.024 \mathrm{mM} / \mathrm{l}$; dissolved oxygen $80 \%$ saturation; $\mathrm{pH}$ 7.2-7.5 throughout the experiment. The water was changed daily in all experimental aquaria. Feces were siphoned out once daily. All fish were fed twice a day at $5 \%$ of their body weight during the period of the experiment.

\section{The experimental diet}

An isocaloric-isonitrogenous diet $(300 \mathrm{~g} / \mathrm{kg}$ crude protein and $107 \mathrm{kj}$ gross energy/100g) was prepared as described by Assem et al., (2014).

\section{Experimental design}

A total number of 420 fish were randomly divided into three equal groups, 140 fish /group. On the basis of the $96 \mathrm{hr} \mathrm{LC}_{50}$ of $43.7 \mathrm{mg} / \mathrm{L}$ for $\mathrm{Cr}^{6+}$ reported by (Abbass and Ali, 2007), two sublethal $\mathrm{Cr}^{6+}$ concentrations $(15$ and $30 \mathrm{mg} / \mathrm{L})$ were prepared in dechlorinated tap water using analytical grade potassium dichromate $\left(\mathrm{K}_{2} \mathrm{Cr}_{2} \mathrm{O}_{7} .7 \mathrm{H}_{2} \mathrm{O}\right)$ as a metal toxicant throughout the experiments. The first group served as a control (without treatment). The other two groups were subjected to the two sublethal concentrations of chromium in water all over the experimental period and lasted 6 weeks for the tested sublethal concentrations. While there was no sign of mortality noticed for the group of fish exposed to the low $\mathrm{Cr}^{6+}$ concentration $(15 \mathrm{mg} / \mathrm{L})$ throughout the whole experimental time. A high mortality rate $(90 \%)$ was recorded in the group treated with the high $\mathrm{Cr}^{6+}(30 \mathrm{mg} / \mathrm{L})$ concentration after two weeks. In order to investigate the possibility of recovery of these groups, the remaining fish $(10 \%$ survival) were directly transferred to a $\mathrm{Cr}^{6+}$ - free media and remained at this condition for further one week. They were assigned to recovery groups. So, recovery group of the low $\mathrm{Cr}^{6+}$ concentration was after the $6^{\text {th }}$ week exposure while it was after the $2^{\text {nd }}$ week exposure for the high $\mathrm{Cr}^{6+}$ concentration using the (10\%) survived fish.

Three groups of 12 fish were killed for each of the applied groups at the end of each experimental time. Blood was sampled from 12 fish of each control and metal exposed groups during each exposure period of 3, 24, 48, 72, $168 \mathrm{hr}, 2,4$, 6 weeks and recovery. Fish were caught by hand net quickly to minimize the disturbance. Then, they were placed upside down and the blood was obtained by incision directly into the heart using a heparinized glass pipette. Blood samples were collected by heart puncture in air-dried, sterile test tubes $(2 \mathrm{mg}$ EDTA $/ \mathrm{ml})$ to estimate hemoglobin (Drabkin and Austim 1932).

Plasma was separated by centrifugation and stored at $-20{ }^{\circ} \mathrm{C}$ for determination of biochemical analysis then the fish was decapitated. Gills and brains were quickly removed, washed with cold saline solution and stored at $-80{ }^{\circ} \mathrm{C}$ to be used for biochemical analysis.

\section{Biochemical analysis}

The plasma Glucose was measured according to the method described by Trinder (1969) using Diamond Diagnostics kits. Total protein was assayed by the method of Lowry et al., (1951). The urea was determined using Biodiagnostics kits according to the method of Fawcett and Scott (1960). The uric acid was determined using enzymatic reaction using Biodiagnostics kits according to the method of Barham and Trinder (1972). The acetylcholinesterase (AChE) was assayed in plasma and brain tissue according to the colorimetric method described by Ellman et al., (1961).The brain was weighted and quickly sonicated in $2 \mathrm{ml}$ of $100 \mathrm{mM}$ phosphate buffer at $\mathrm{pH} 4.2$ using an ultrasonic power with cooling during and between each period of sonication. The homogenate was centrifuged in centrifuge at $800 \mathrm{~g}=25000$ rpm for $20 \mathrm{~min}$. The supernatant was transferred to clean test tube immersed in an ice bath and analyzed for the enzyme activity. Gill $\mathrm{Na}^{+}-\mathrm{K}^{+}$-ATPase was measured and 
calculated as the difference between rates of inorganic phosphate liberated in the presence and absence of Ouabain. The released inorganic phosphate was measured according to the method of Fiske and Subbarow (1925). The protein concentration was determined by the method of Lowy et al., 1951. Enzyme activity was expressed as $\mu \mathrm{M} \mathrm{Pi} / \mathrm{mg}$ protein $/ \mathrm{hr}$. Metallothionein concentration was determined in the hepatic tissue according to Linde and Vazquez (2006).

Statistical analysis

The means and standard error of means, as well as one-way analysis of variance (ANOVA) for statistical significance $(\mathrm{P}<0.01)$, were used to determine significant differences in all parameters measured. All the statistics were carried out using Statistical Analysis System (SAS Institute, Inc., 2004. SAS/SHARE ${ }^{\circledR} 9.1$ User's Guide. SAS Institute Inc., Cary, NC, 27513, USA.).

\section{RESULTS}

\section{Plasma glucose}

Plasma glucose level (Table 1) rapidly increased $3 \mathrm{hr}$ after transferring the fish to the $\mathrm{Cr}^{6+}$ containing aquaria at both concentrations. This initial significant increase extended throughout the remaining time interval till the $2^{\text {nd }}$ week for both $\mathrm{Cr}^{6+}$ sublethal concentrations. A recovery of the glucose level in fish plasma was recorded after the $6^{\text {th }}$ week of exposure to the lower concentration and at $3^{\text {rd }}$ week for the higher concentration after entering recovery aquaria

\section{Plasma hemoglobin}

The hemoglobin content (Table 1) decreased significantly at both $\mathrm{Cr}^{6+}$ concentrations when compared to the control group throughout the whole experimental periods. No sign of recovery was recorded.

Table 1: Changes in plasma glucose $(\mathrm{mg} / \mathrm{dl})$ and hemoglobin content $(\mathrm{g} / \mathrm{dl})$ during exposure to two sublethal concentrations of $\mathrm{Cr}^{6+}$

\begin{tabular}{|c|c|c|c|c|}
\hline \multirow[b]{2}{*}{ Experimental condition } & \multicolumn{2}{|c|}{ Plasma glucose $(\mathrm{mg} / \mathrm{dl})$} & \multicolumn{2}{|c|}{ Hemoglobin content (g/dl) } \\
\hline & $\begin{array}{c}15 \mathrm{mg} / \mathrm{l} \\
(\mathrm{Mean} \pm \mathrm{SE})\end{array}$ & $\begin{array}{c}30 \mathrm{mg} / \mathrm{l} \\
(\mathrm{Mean} \pm \mathrm{SE})\end{array}$ & $\begin{array}{c}15 \mathrm{mg} / \mathrm{l} \\
(\mathrm{Mean} \pm \mathrm{SE})\end{array}$ & $\begin{array}{c}30 \mathrm{mg} / \mathrm{l} \\
(\mathrm{Mean} \pm \mathrm{SE})\end{array}$ \\
\hline Control & $39.28 \pm 0.64^{h i}$ & $39.28 \pm 0.64^{h i}$ & $4.73 \pm 0.11^{a}$ & $4.73 \pm 0.11^{a}$ \\
\hline $3 \mathrm{hr}$ & $61.56^{* *} \pm 2.43^{b c d e f}$ & $53.62^{* *} \pm 3.60^{e f g}$ & $3.48^{* *} \pm 0.28^{b c d}$ & $3.54^{* *} \pm 0.21^{b c}$ \\
\hline $24 \mathrm{hr}$ & $53.89^{* *} \pm 2.42^{e f g}$ & $71.95^{* *} \pm 3.92^{b}$ & $3.45^{* *} \pm 0.12^{b c d}$ & $3.77^{* *} \pm 0.17^{b}$ \\
\hline $48 \mathrm{hr}$ & $53.43^{* *} \pm 0.69^{e f g}$ & $69.75^{* *} \pm 5.07^{b c}$ & $2.76^{* *} \pm 0.21^{d e}$ & $3.67^{* *} \pm 0.23^{b c}$ \\
\hline $72 \mathrm{hr}$ & $51.20^{* *} \pm 2.45^{f g}$ & $83.27^{* *} \pm 4.10^{a}$ & $3.38^{* *} \pm 0.34^{b c d}$ & $3.76^{* *} \pm 0.12^{b}$ \\
\hline $168 \mathrm{hr}$ & $60.04^{* *} \pm 2.68^{c d e f}$ & $92.65^{* *} \pm 8.82^{a}$ & $3.78^{* *} \pm 0.16^{b}$ & $3.13^{* *} \pm 0.19^{b c d}$ \\
\hline 2 weeks & $67.84^{* *} \pm 3.19^{b c d}$ & $61.97^{* *} \pm 8.39^{b c d e}$ & $2.99^{* *} \pm 0.23^{\text {cde }}$ & $3.80^{* *} \pm 0.07^{b}$ \\
\hline 4 weeks & $58.07^{* *} \pm 2.73^{\text {def }}$ & & $3.58^{* *} \pm 0.21^{b}$ & 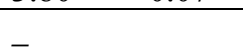 \\
\hline 6 weeks & $30.45 \pm 1.14^{i}$ & & $3.72^{* *} \pm 0.13^{b c}$ & \\
\hline Recovery $^{z}$ & $\pm 1.05^{i}$ & $46.48 \pm 0.65^{h g}$ & $3.69^{* *} \pm 0.14^{b c}$ & $2.28^{* *} \pm 0.08^{e}$ \\
\hline
\end{tabular}

$\mathrm{SE}=$ Standard error of the mean, ${ }^{* *}=P<0.01$. Means \pm SE followed by the same superscript letter (s) are not significantly different at $P<0.01$. ( $\mathrm{n}=12 \mathrm{fish})$, Recovery $^{z}=$ Was after 6 weeks exposure, for the $15 \mathrm{mg} / \mathrm{L}$ group and after 2 weeks exposure for the $30 \mathrm{mg} / \mathrm{L}$ group with the $10 \%$ survived fish.

\section{Plasma urea}

The results showed a significant decrease in the plasma urea of fish treated with the two concentration of chromium as compared to the control group after $24 \mathrm{hr}$ of exposure (Table 2). This initial decrease was followed by an increase above control after $72 \mathrm{hr}$ of exposure, thereafter, it tended to decrease to control level throughout the rest of exposure time. 
Table 2: Changes in urea content $(\mathrm{mg} / \mathrm{dl})$ and uric acid content $(\mathrm{mg} / \mathrm{dl})$ during exposure to two sublethal concentrations of $\mathrm{Cr}^{6+}$.

\begin{tabular}{|c|c|c|c|c|}
\hline \multirow[b]{2}{*}{ Experimental condition } & \multicolumn{2}{|c|}{ Urea content (mg/dl) } & \multicolumn{2}{|c|}{ Uric acid content (mg/dl) } \\
\hline & $\begin{array}{c}15 \mathrm{mg} / \mathrm{l} \\
(\mathrm{Mean} \pm \mathrm{SE})\end{array}$ & $\begin{array}{c}30 \mathrm{mg} / \mathrm{l} \\
(\mathrm{Mean} \pm \mathrm{SE})\end{array}$ & $\begin{array}{c}15 \mathrm{mg} / \mathrm{l} \\
(\mathrm{Mean} \pm \mathrm{SE})\end{array}$ & $\begin{array}{c}30 \mathrm{mg} / \mathrm{l} \\
(\mathrm{Mean} \pm \mathrm{SE})\end{array}$ \\
\hline Control & $5.60 \pm 0.10^{\text {cde }}$ & $5.60 \pm 0.10^{\text {cde }}$ & $0.68 \pm 0.03^{h}$ & $0.68 \pm 0.03^{h}$ \\
\hline $3 \mathrm{hr}$ & $4.52 \pm 0.32^{e f g}$ & $4.23^{* *} \pm 0.35^{f g}$ & $0.71 \pm 0.05^{g h}$ & $0.84 \pm 0.08^{\text {defgh }}$ \\
\hline $24 \mathrm{hr}$ & $3.58^{* *} \pm 0.46^{g}$ & $5.87 \pm 0.26^{c d}$ & $0.70 \pm 0.04^{g h}$ & $0.72 \pm 0.03^{g h}$ \\
\hline $48 \mathrm{hr}$ & $6.29 \pm 0.69^{c d}$ & $6.57 \pm 1.01^{\mathrm{cd}}$ & $0.79 \pm 0.05^{\text {efgh }}$ & $0.91 \pm 0.03^{\text {defgh }}$ \\
\hline $72 \mathrm{hr}$ & $9.84^{* *} \pm 0.92^{a}$ & $9.52^{* *} \pm 0.25^{a b}$ & $1.00^{* *} \pm 0.02^{\text {defg }}$ & $1.04^{* *} \pm 0.05^{\text {cdef }}$ \\
\hline $168 \mathrm{hr}$ & $6.03 \pm 0.25^{c d}$ & $8.42^{* *} \pm 0.34^{b}$ & $0.74 \pm 0.04^{f g h}$ & $1.37^{* *} \pm 0.27^{b}$ \\
\hline 2 weeks & $6.47 \pm 0.24^{c d}$ & $6.83 \pm 0.45^{c}$ & $1.15^{* *} \pm 0.05^{b c d}$ & $1.76^{* *} \pm 0.22^{a}$ \\
\hline 4 weeks & $\pm 0.11^{c d}$ & & $1.33^{* *} \pm 0.15^{b c}$ & \\
\hline 6 weeks & $\pm 0.21^{c d}$ & & $1.05^{* *} \pm 0.18^{\text {cde }}$ & \\
\hline Recovery $^{z}$ & $\pm 0.51^{c d}$ & $5.45 \pm 0.39^{d e f}$ & $\pm 0.06^{g h}$ & $0.59 \pm 0.10^{h}$ \\
\hline
\end{tabular}

$\mathrm{SE}=$ Standard error of the mean, ${ }^{* *}=P<0.01$. Means \pm SE followed by the same superscript letter (s) are not significantly different at $P<0.01$. ( $\mathrm{n}=12$ fish), Recovery ${ }^{\mathrm{z}}=$ Was after 6 weeks exposure, for the 15 $\mathrm{mg} / \mathrm{L}$ group and after 2 weeks exposure for the $30 \mathrm{mg} / \mathrm{L}$ group with the $10 \%$ survived fish.

\section{Plasma uric acid}

The uric acid level in plasma increased significantly after $72 \mathrm{hr}$ of exposure with low $\mathrm{Cr}^{6+}$ concentration as compared to the control (Table 2). The increase extended onwards until the end of the experiment. The recovery for this concentration was observed in plasma of the fish group assigned as recovery group. In the case of high $\mathrm{Cr}^{6+}$ concentration, a similar response was recorded, as the plasma uric acid concentration also increased during the whole exposure interval reaching a maximum after two weeks of exposure. Recovery to control was recorded in the fish group assigned as recovery group.

\section{Plasma AChE activity}

Table (3) showed a significant AChE enzyme inhibition in fish exposed to 15 $\mathrm{mg} / \mathrm{L}$ or $30 \mathrm{mg} / \mathrm{L} \mathrm{Cr}^{6+}$ for $3 \mathrm{hr}$ to $48 \mathrm{hr}$. There was no recovery recorded in all the experimental groups.

Table 3: Changes in plasma AChE specific activity (U/mg protein) and plasma total protein concentration $(\mathrm{mg} / \mathrm{ml})$ during exposure to two sublethal concentrations of $\mathrm{Cr}^{6+}$

\begin{tabular}{|c|c|c|c|c|}
\hline \multirow{2}{*}{ Experimental condition } & \multicolumn{2}{|c|}{$\begin{array}{c}\text { Plasma AChE specific activity } \\
\text { (U/mg protein) }\end{array}$} & \multicolumn{2}{|c|}{$\begin{array}{l}\text { Plasma total protein concentration } \\
\qquad(\mathrm{mg} / \mathrm{ml})\end{array}$} \\
\hline & $\begin{array}{c}15 \mathrm{mg} / \mathrm{l} \\
(\mathrm{Mean} \pm \mathrm{SE})\end{array}$ & $\begin{array}{c}30 \mathrm{mg} / 1 \\
(\mathrm{Mean} \pm \mathrm{SE})\end{array}$ & $\begin{array}{c}15 \mathrm{mg} / \mathrm{l} \\
(\mathrm{Mean} \pm \mathrm{SE})\end{array}$ & $\begin{array}{c}30 \mathrm{mg} / 1 \\
(\mathrm{Mean} \pm \mathrm{SE})\end{array}$ \\
\hline Control & $0.052 \pm 0.002^{a b}$ & $0.052 \pm 0.002^{\mathrm{a} b}$ & $6.61 \pm 0.09^{a b}$ & $6.61 \pm 0.09^{a b}$ \\
\hline $3 \mathrm{hr}$ & $0.035^{* *} \pm 0.028^{e}$ & $0.037^{* *} \pm 0.002^{d e}$ & $6.82 \pm 0.13^{a}$ & $5.81^{* *} \pm 0.24^{C}$ \\
\hline $24 \mathrm{hr}$ & $0.044^{* *} \pm 0.002^{c d}$ & $0.032^{* *} \pm 0.003^{e f g}$ & $6.53 \pm 0.12^{a b c}$ & $6.82 \pm 0.09^{a}$ \\
\hline $48 \mathrm{hr}$ & $0.025^{* *} \pm 0.004^{g h}$ & $0.019^{* *} \pm 0.003^{h}$ & $6.47 \pm 0.31^{a b c d}$ & $5.99 \pm 0.28^{b c}$ \\
\hline $72 \mathrm{hr}$ & $0.035^{* *} \pm 0.002^{e}$ & $0.055 \pm 0.004^{a}$ & $6.68 \pm 0.15^{a b}$ & $6.41 \pm 0.19^{a b c}$ \\
\hline $168 \mathrm{hr}$ & $0.057 \pm 0.005^{a}$ & $0.055 \pm 0.003^{a}$ & $4.95^{* *} \pm 0.22^{d}$ & $5.79^{* *} \pm 0.40^{c}$ \\
\hline 2 weeks & $0.046 \pm 0.002^{b c}$ & $0.035^{* *} \pm 0.004^{e}$ & $4.59^{* *} \pm 0.26^{d}$ & $4.32^{* *} \pm 0.29^{d}$ \\
\hline 4 weeks & $0.026^{* *} \pm 0.002^{f g h}$ & & $4.31^{* *} \pm 0.30^{d}$ & \\
\hline 6 weeks & $0.036^{* *} \pm 0.028^{d e}$ & & $3.32^{* *} \pm 0.05^{e}$ & \\
\hline Recovery $^{z}$ & $0.033^{* *} \pm 0.003^{\text {efg }}$ & $0.034^{* *} \pm 0.003^{e f}$ & $4.59^{* *} \pm 0.40^{d}$ & $5.03^{* *} \pm 0.40^{d}$ \\
\hline
\end{tabular}

$\mathrm{SE}=$ Standard error of the mean, ${ }^{* *}=P<0.01$. Means \pm SE followed by the same superscript letter (s) are not significantly different at $P<0.01$. ( $\mathrm{n}=12$ fish), Recovery ${ }^{\mathrm{z}}=$ Was after 6 weeks exposure, for the $15 \mathrm{mg} / \mathrm{L}$ group and after 2 weeks exposure for the $30 \mathrm{mg} / \mathrm{L}$ group with the $10 \%$ survived fish. 


\section{Plasma protein}

Plasma protein concentration was significantly decreased in fish group exposed to $15 \mathrm{mg} / \mathrm{L} \mathrm{Cr}^{6+}$ after $168 \mathrm{hr}$ when compared to the control group (Table 3). It continued to decrease significantly by exposure 2 weeks till it reached its minimum value by 6 weeks of exposure compared to control. Exposure to $30 \mathrm{mg} / \mathrm{L} \mathrm{Cr}{ }^{6+}$ showed a similar response to the low $\mathrm{Cr}^{6+}$ concentration, but the decrease started $3 \mathrm{hr}$ earlier and continued to two weeks. There was no sign of recovery recorded in all the exposure groups.

\section{Brain AChE activity}

The results of brain AChE activity of fish $3 \mathrm{hr}$ exposed to the low concentration of $\mathrm{Cr}^{6+}$ showed a significant $(\mathrm{P}<0.01)$ inhibition (Table 4). This initial inhibition was followed by an activation that lasted during the next $48 \mathrm{hr}$. Exposure to $72 \mathrm{hr}$ until the end of the experiment showed a tendency toward the control level. The enzyme activity showed a significant increase in groups treated with the high $\mathrm{Cr}^{6+}$ concentration. This increase lasted throughout the whole experiment period without any sign of recovery to the control level.

Table 4: Changes in brain AChE specific activity (U/g protein) and brain total protein content (mg/100 $\mathrm{mg}$ ) during exposure to two sublethal concentrations of $\mathrm{Cr}^{6+}$

\begin{tabular}{|c|c|c|c|c|}
\hline \multirow{2}{*}{ Experimental condition } & \multicolumn{2}{|c|}{$\begin{array}{c}\text { Brain AChE specific activity } \\
\text { (U/g protein) }\end{array}$} & \multicolumn{2}{|c|}{$\begin{array}{l}\text { Brain total protein content } \\
(\mathrm{mg} / 100 \mathrm{mg})\end{array}$} \\
\hline & $\begin{array}{c}15 \mathrm{mg} / \mathrm{l} \\
(\mathrm{Mean} \pm \mathrm{SE})\end{array}$ & $\begin{array}{c}30 \mathrm{mg} / \mathrm{l} \\
(\mathrm{Mean} \pm \mathrm{SE})\end{array}$ & $\begin{array}{c}15 \mathrm{mg} / \mathrm{l} \\
(\mathrm{Mean} \pm \mathrm{SE})\end{array}$ & $\begin{array}{c}30 \mathrm{mg} / \mathrm{l} \\
(\mathrm{Mean} \pm \mathrm{SE})\end{array}$ \\
\hline Control & $274.85 \pm 17.71^{c}$ & $274.85 \pm 17.71^{c}$ & $2.76 \pm 0.17^{f g}$ & $2.76 \pm 0.17^{f g}$ \\
\hline $3 \mathrm{hr}$ & $179.17^{* *} \pm 21.47^{d}$ & $423.49^{* *} \pm 36.33^{b}$ & $3.70^{* *} \pm 0.33^{a b}$ & $3.47^{* *} \pm 0.20^{a b c d}$ \\
\hline $24 \mathrm{hr}$ & $453.72^{* *} \pm 44.85^{b}$ & $458.17^{* *} \pm 43.553^{b}$ & $3.40^{* *} \pm 0.19^{a b c d e}$ & $3.75^{* *} \pm 0.19^{a b}$ \\
\hline $48 \mathrm{hr}$ & $597.10^{* *} \pm 38.27^{a}$ & $442.94^{* *} \pm 10.161^{b}$ & $3.52^{* *} \pm 0.23^{a b c}$ & $3.81^{* *} \pm 0.18^{a}$ \\
\hline $72 \mathrm{hr}$ & $281.33 \pm 13.75^{c}$ & $431.26^{* *} \pm 12.850^{b}$ & $3.65^{* *} \pm 0.18^{a b}$ & $3.20 \pm 0.15^{\text {bcdefg }}$ \\
\hline $168 \mathrm{hr}$ & $300.43 \quad \pm 38.31^{c}$ & $448.75^{* *} \pm 5.413^{b}$ & $3.60^{* *} \pm 0.20^{a b c}$ & $3.20 \pm 0.17^{b c d e f g}$ \\
\hline 2 weeks & $\pm 27.95^{c}$ & $617.11^{* *} \pm 33.57^{a}$ & $3.21 \pm 0.16^{\text {bcdef }}$ & $2.86 \pm 0.31^{e f g}$ \\
\hline 4 weeks & $238.04 \quad \pm 7.354^{\text {cd }}$ & - & $2.61 \pm 0.18^{g}$ & - \\
\hline 6 weeks & $263.24 \pm 19.949^{C}$ & & $3.04 \pm 0.17^{\text {cdefg }}$ & \\
\hline Recovery $^{\mathrm{Z}}$ & $313.36 \pm 30.70^{c}$ & $400.53^{* *} \pm 32.57^{b}$ & $2.88 \pm 0.14^{\text {efg }}$ & $2.92 \pm 0.19^{\text {defg }}$ \\
\hline
\end{tabular}

$\mathrm{SE}=$ Standard error of the mean, ${ }^{* *}=P<0.01$. Means \pm SE followed by the same superscript letter (s) are not significantly different at $P<0.01$. (n= 12 fish), Recovery ${ }^{z}=$ Was after 6 weeks exposure, for the $15 \mathrm{mg} / \mathrm{L}$ group and after 2 weeks exposure for the $30 \mathrm{mg} / \mathrm{L}$ group with the $10 \%$ survived fish.

\section{Gill $\mathrm{Na}^{+}-\mathrm{K}^{+}$ATPase activity}

No significant variations were measured during all experimental period for both $\mathrm{Cr}^{6+}$ concentrations (Table 5), and gill $\mathrm{Na}^{+}-\mathrm{K}^{+}$ATPase activity remained more or less unchanged in comparison with that of the control.

\section{Metallothionein (MT)}

The MTs content of the low $\mathrm{Cr}^{6+}$ concentration (15mg/l) group (Table 6) recorded a significant increase after exposure to 3,48, $72 \mathrm{hr}$ and 2 weeks as compared to the control. Also, $30 \mathrm{mg} / \mathrm{L} \mathrm{Cr}^{6+}$ concentration induced a significant increase in MTs in fish until 2 weeks. 
Table 5: Changes in $\mathrm{Na}^{+}-\mathrm{K}^{+}$ATPase specific activity $(\mu \mathrm{mol} \mathrm{Pi} / \mathrm{mg}$ protein/ $\mathrm{h}$ )

\begin{tabular}{|c|c|c|}
\hline \multirow{2}{*}{ Experimental condition } & \multicolumn{2}{|c|}{$\begin{array}{c}\mathrm{Na}^{+}-\mathrm{K}^{+} \text {ATPase specific activity } \\
(\mu \mathrm{mol} \mathrm{Pi} / \mathrm{mg} \text { protein } / \mathrm{h})\end{array}$} \\
\hline & $\begin{array}{c}15 \mathrm{mg} / \mathrm{l} \\
(\mathrm{Mean} \pm \mathrm{SE})\end{array}$ & $\begin{array}{c}30 \mathrm{mg} / \mathrm{l} \\
(\mathrm{Mean} \pm \mathrm{SE})\end{array}$ \\
\hline Control & $2.29 \pm 0.34^{\text {bcdef }}$ & $2.29 \pm 0.34^{\text {bcdef }}$ \\
\hline $3 \mathrm{hr}$ & $2.20 \pm 0.41^{b c d e f}$ & $2.16 \pm 0.12^{\text {bcdef }}$ \\
\hline $24 \mathrm{hr}$ & $1.43 \pm 0.70^{e f}$ & $1.10 \pm 0.20^{f}$ \\
\hline $48 \mathrm{hr}$ & $1.78 \pm 0.16^{\text {cdef }}$ & $1.61 \pm 0.17^{\text {def }}$ \\
\hline $72 \mathrm{hr}$ & $1.74 \pm 0.22^{\text {cdef }}$ & $3.03 \pm 0.67^{b c}$ \\
\hline $168 \mathrm{hr}$ & $2.58 \pm 0.93^{b c d e}$ & $3.00 \pm 0.27^{b c d}$ \\
\hline 2 weeks & $2.56 \pm 0.69^{\text {bcde }}$ & $2.85 \pm 0.42^{b c d}$ \\
\hline 4 weeks & $2.47 \pm 0.26^{\text {bcdef }}$ & \\
\hline 6 weeks & $2.58 \pm 0.30^{b c d e}$ & \\
\hline Recovery $^{z}$ & $4.71^{*} \pm 0.73^{a}$ & $3.48 \pm 0.46^{a b}$ \\
\hline
\end{tabular}

$\mathrm{SE}=$ Standard error of the mean, ${ }^{* *}=P<0.01$. Means \pm SE followed by the same superscript letter $(\mathrm{s})$ are not significantly different at $P<0.01$. ( $\mathrm{n}=12$ fish), Recovery ${ }^{\mathrm{z}}=$ Was after 6 weeks exposure, for the15 $\mathrm{mg} / \mathrm{L}$ group and after 2 weeks exposure for the $30 \mathrm{mg} / \mathrm{L}$ group with the $10 \%$ survived fish.

Table 6: Changes in metallothionein (MT) ( $\mu \mathrm{g} / \mathrm{g}$ tissue) during exposure to two sublethal concentrations of $\mathrm{Cr}^{6+}$

\begin{tabular}{|c|c|c|}
\hline \multirow{2}{*}{ Experimental condition } & \multicolumn{2}{|c|}{ Treatment } \\
\cline { 2 - 3 } & $\begin{array}{c}15 \mathrm{mg} / 1 \\
(\text { Mean } \pm \text { SE) }\end{array}$ & $\begin{array}{c}30 \mathrm{mg} / 1 \\
(\text { Mean } \pm \text { SE })\end{array}$ \\
\hline Control & $95.59 \pm 2.51^{g}$ & $95.59 \pm 2.51^{g}$ \\
\hline $3 \mathrm{hr}$ & $106.74^{* *} \pm 1.20^{\text {de }}$ & $108.03^{* *} \pm 0.86^{d}$ \\
\hline $24 \mathrm{hr}$ & $100.96 \pm 0.74^{f g}$ & $122.47^{* *} \pm 0.64 \mathrm{~b}^{b c}$ \\
\hline $48 \mathrm{hr}$ & $118.32^{* *} \pm 0.08^{c}$ & $125.29^{* *} \pm 1.40^{b}$ \\
\hline $72 \mathrm{hr}$ & $121.32^{* *} \pm 18.49^{b c}$ & $120.51^{* *} \pm 0.33^{b c}$ \\
\hline $168 \mathrm{hr}$ & $97.28^{* *} \pm 0.01^{f g}$ & $142.05^{* *} \pm 1.33^{a}$ \\
\hline 2 weeks & $101.37^{* *} \pm 0.31^{\text {ef }}$ & $118.99^{* *} \pm 2.26^{c}$ \\
\hline 4 weeks & $100.11^{f g} \pm 0.65^{f g}$ & - \\
\hline
\end{tabular}

$\mathrm{SE}=$ Standard error of the mean, ${ }^{* *}=P<0.01$. Means \pm SE followed by the same superscript letter (s) are not significantly different at $P<0.01$. (n=12 fish)

\section{DISCUSSION}

In the aquatic environment, dissolved metals occur naturally in trace amounts, nevertheless, they may be transported, concentrated, altered into different structures through industry and are reinserted into the aquatic system as pollutants. Accordingly, fishes in polluted regions are frequently subjected to much higher concentrations or to chemical forms of many pollutants. $\mathrm{Cr}^{6+}$ is a standout amongst the most well-known substantial metal toxins in the environment, released with the effluents of leather, stainless steel, electroplating, wood preservation, textile factories and different other industries. The haphazard release of these heavy metals into water resources might produce a critical risk to the subsistence of aquatic fauna including fish populations.

It seems that the hematological assessment may reflect the pathophysiological state of the entire body; therefore, estimating blood indices is of importance for the diagnosis of the fish status after toxicant exposure (Adhikari et al., 2004). In the present study, a decline in hemoglobin concentration was noticed after $3 \mathrm{hr}$ of exposure to both $\mathrm{Cr}^{6+}$ concentrations and lasted throughout the whole experiment. These changes may be due to the alterations of the properties of hemoglobin through declining capacity of their oxygen binding affinity, which likely would lead to cell bulging distortion and injury (Witeska and Kosciuk, 2003). Vaseem and Banerjee, 
(2012) reported that the decline in hemoglobin levels was an indication of a highly limited fish's ability to get enough oxygen in their tissues and as a result, their physical activity would be restricted. Either the increase in the destruction rate of hemoglobin or the decrease in its rate of synthesis might be considered the cause of the considerably recorded decrease in the hemoglobin concentration. Shah and Altindag (2005) notified a similar observation recorded by the fish Tinca tinca when being subjected to mercuric chloride and lead. Shalaby (2001) stated that the extended decrease in hemoglobin content was deleterious to oxygen transfer and any blood abnormalities and degeneration of the erythrocytes could be attributed to pathological conditions in fishes exposed to toxicants. The distinct reduction in the level of hemoglobin after exposure to $\mathrm{Cr}^{6+}$ may suggest a hemodilution mechanism probably as a result of the damage in the gills or impaired osmoregulation (Praveena et al., 2013). The hemodilution has been explicated as a mechanism that diminishes the concentration of the annoying factor in the circulatory system (Vaseem, and Banerjee, 2012; Assem et al., 2014). Low hemoglobin usually means the animal has anemia.

Blood glucose alterations have been proposed as a good indicator of stress, which is probably the most common and easily estimated response to stresses in fish (Hassan et al., 2013). The obtained data revealed that plasma glucose levels were increased significantly at both sublethal $\mathrm{Cr}^{6+}$ concentrations. This increase might be due to an elevation necessary for the increased metabolic demands.

Urea, uric acid, creatinine, and bilirubin are nitrogenous waste products correlated with fishes (Kori-Siakpere, 2008). A major nitrogen-containing metabolic product of protein catabolism is blood urea nitrogen, which acts as a major osmolyte; hence, it can be used as a sentient tool for gill and kidney dysfunction prediction in fish (McDonald and Grosell, 2006). The decreased plasma urea in the present work may be attributed to the decreased plasma protein level while the elevation may be due to dysfunction of gills or kidney. This suggestion is supported by El-Boshy et al., (2014) who reported that gill damage was as a result of cadmium intoxication in Gasterosteus aculeatus. In the same aspect, Öner et al., (2008) reported decreased blood urea in chromium-exposed fish, O. niloticus.

Uric acid is formed by fish from exogenous and endogenous purines, which is produced from the breakdown of body cells and the consumed food. Plasma uric acid can be used as a rough index of the glomerular filtration rate (Adham, et al., 2002). Low concentrations of plasma uric acid had no significance, but high values could be used as indicators of kidney dysfunction (Zaghloul et al., 2007). Accumulation of heavy metals in the kidney induced damage of the renal cells leading to nephropathy.

In the present work, the considerable increase in the uric acid level may be attributed to the effect of $\mathrm{Cr}^{6+}$ on the filtration rate of the glomeruli (El-Bagori, 2001; Abbass et al., 2002). The increasing uric acid concentration in the blood may suggest the inability of the kidney to excrete these products. Shi et al., (2005) documented liver damage in Carassius auratus exposed to cadmium. However, Adham, et al. (2002) mentioned that uric acid elevation could also occur due to increased muscular tissue catabolism, decreased urinary clearance by the kidney, increased synthesis or decreased degradation of these compounds.

The acetylcholinesterase activity can be used as a biomarker of exposure (Da Cuna et al., 2011; Xu et al., 2011). It could be an earnest biomarker for the assessment of neurotoxic changes in cases of toxicant exposure (GholamiSeyedkolaei et al., 2013). Brain AChE activity showed significant inhibition after $3 \mathrm{hr}$ of exposure to the low concentration of $\mathrm{Cr}^{6+}$. It was considered as a real change confirmed by a simultaneous significant increase in brain protein content. The 
fluctuations of inhibition and activation and final recovery may be due to a mechanism involved in the homeostasis of fish to stress. The recorded opposite results obtained in groups exposed to the high concentration of $\mathrm{Cr}^{6+}$ produced brain AChE activation that extended until the end of experiments with no recorded recovery seems to represent an alarm reaction to the presence of $\mathrm{Cr}^{6+}$ during which more nerve impulse transfer might be needed. Our results are compatible with those obtained by Guzmán-Guillén et al., (2015) who reported that the brain of tilapia (O. niloticus) subchronically exposed to repeated concentrations of $10 \mu \mathrm{g}$ Cylindrospermopsin $(\mathrm{CYN} / \mathrm{L})$ showed a first AChE inhibition, followed by recovery and finally activation.

The inhibition of acetylcholinesterase activity is considered as a biomarker of xenobiotic effect on the nervous system (Lionetto et al., 2013). Therefore, the inhibition of $\mathrm{AChE}$ recorded in the present study may be a biomarker for the toxic effect of $\mathrm{Cr}^{6+}$ on fishes.

Plasma total proteins may play a remarkable part in the metabolism and regulation of water balance (Heath, 1995). In the present study, plasma protein was significantly decreased in both $\mathrm{Cr}^{6+}$ sublethal concentrations. Zaghloul et al., (2007) stated that the recorded hypoproteinemia might be explained on the basis of production of energy throughout pollutant toxicity and/or due to other several pathological processes including renal damage and elimination in hepatic blood flow and/or plasma dissolution. These results may also be attributed to the disturbances in the metabolism of liver protein due to Cr toxicity, as it was noticed in the case of other contaminants (Abdel-Tawwab et al., 2007a, b).

Ion transport across membranes to preserve the physiological demands of the cell are known to be regulated by ion-dependent ATPases (Agrahari and Gopal, 2008; Hegazi et al., 2015). The present data display a decreasing tendency in $\mathrm{Na}^{+}-\mathrm{K}^{+}-$ ATPase activity throughout the whole experiment but it was not significant. It could be a technique for ion imbalance resulting from chromium exposure.

The present results showed that $\mathrm{Cr}^{6+}$ exposure caused a considerable increase in MT concentrations in the liver of $O$. niloticus. It is renowned that these molecules are important sources of thiols for hindering the interactions of metals with main cellular structures as a first line of defense. So, boosted MT concentration might be due to the probable Cr toxicity in this tissue, which is the main metals storage organ and place where biochemical parameters such as MT involved in detoxification mechanisms. The present data were in agreement with those obtained by Atli and Canli, 2003, where MT level increased in the liver of O. niloticus exposed to Cadmium. It was also similar to the results obtained by Linde and Vazquez 2006, where O. niloticus and Geophagus brasiliensis were collected from two polluted locations. In the present study, the MT was sensitive in fish during exposure to both concentrations. The magnitude of the increase was concentration dependent being higher in fish exposed to the $\mathrm{Cr}$ at its higher concentration $(30 \mathrm{mg} / \mathrm{L})$ and remained higher than the control till the end of the experiments. This indicated that the MT is sensitive to the presence of $\mathrm{Cr}^{6+}$ with different concentrations and considered to be a valuable biomarker of defense.

In conclusion, biochemical parameters such as glucose, urea, uric acid, plasma, and brain AChE in Oreochromis niloticus showed different alterations because extended metallic stress in fish makes adaptability hard and generates feebleness in fish. These indices could be effectively used as possible indicators of heavy metal toxicity in the freshwater fish environmental biomonitoring field. In our experiment we observe that blood hemoglobin, plasma glucose followed by brain acetylcholinesterase are shown as more sensitive indicators. Liver MT might be 
considered as a susceptible biochemical indicator in ecotoxicological studies since it was enhanced in the presence of both $\mathrm{Cr}^{6+}$ concentrations and so it was nominated as a valuable biomarker of defense. Furthermore, the changes of plasma AChE might also be considered as a biomarker of defense, nonetheless, this should require more studies. We recommended the use of all these parameters as biomarkers in closed systems as in aquaculture. However, the value of the studied biomarkers of defense or exposure in the Nile and northern lakes might need a different approach.

\section{REFERENCES}

Abbass, H.H. and Ali, F.K. (2007). Study the effect of hexavalent chromium on some biochemical, cytotoxicological and histopathological aspects of the Oreochromis spp. Fish, Pak J Biol. Sci., 10: 3973-3982.

Abbass, H. H.; Zaghloul, K. H. and Mousa, M. A. A. (2002). Effect of some heavy metal pollutants on some biochemical and histopathological changes in blue tilapia; Oreochomis niloicus. Egypt J Agricult, Res., 80(3):1385-1411.

Abdallah, M. A. M. (2014). Chromium geochemistry in coastal environment of the Western Harbour, Egypt: water column, suspended matter and sediments. J Coast Conserv , 18:1-10 DOI 10.1007/s11852-013-0288-6.

Abdel-Sabour, M.F. (2007). Chromium in receiving environment in Egypt (an overview). Electronic J Environ Agricult Food Chemistry, 6 (7):2178-2198.

Abdel-Tawwab, M.; Mousa, M. A. A. and Abbass, F. E. (2007a). Growth performance and physiological response of African catfish, Clarias gariepinus (B.) fed organic selenium prior to the exposure to environmental copper toxicity. Aquacult., 272 (1-4):335-345.

Abdel-Tawwab, M.; Mousa, M. A. A.; Ahmad, M. H. and Sakr, S. F. (2007b). The use of calcium pre-exposure as a protective agent against environmental copper toxicity for juvenile Nile tilapia, Oreochromis niloticus (L.). Aquaculture, 264: 236-246.

Adham, K.; G. A., Ibrahim, H. M.; Hamed, S. S. and Saleh, R. A. (2002). Blood chemistry of the Nile tilapia, Oreochromis niloticus (Linnaeus, 1757) under the impact of water pollution. Aquat. Ecol., 36: 549-557.

Adhikari, S.; Sarkar, B.; Chatterjee, A.; Mahapatra, C.T. and Ayyappan, S. (2004). Effects of Cypermethrin and carboforan on certain haematological parameters and prediction of their recovery in a fresh water teleost, Labeo rohita (Hamilton). Ecotoxicol Environ. Saf., 58: 220-226.

Agrahari, S. and Gopal, K. (2008). Inhibition of $\mathrm{Na}^{+}-\mathrm{K}^{+}$-ATPase in different tissues of freshwater fish Channa punctatus (Bloch) exposed to monocrotophos. Pestic Biochem Physiol, 92:57-60.

Assem, H.; Hassan, B.; Khalifa, A.; El-Salhia, M.; Al Basomy, A. and El-Sayed, M. (2013). The combined effect of environmental thermal drop and isotonicity on metabolic stores of the teleost, Oreochromis niloticus. Egypt J Aquat. Res., 40: $17-21$.

Assem, H.; Khalifa, A. and El-Salhia, M. (2014). Physiological and microbiological indices as indicators of evaluating dietary fungi degraded date pits as a probiotic for cultured Nile tilapia Oreochromis niloticus fingerling and its effect on fish welfare. Egypt J. Aquat. Res., 40: 435-441.

Assis C.R.D.; Linhares, A. G; Oliveira, V. M.; Penha Franca, R. C.; Santos, J. F.; Marcuschi, M.; Carvalho, E.V.M.M.; Bezerra, R.S. and Carvalho Jr, L. B. 
(2014). Characterization of catalytic efficiency parameters of brain cholinesterases in tropical fish. Fish Physiol Biochem, 40:1659-1668.

Atli, G. and Canli, M. (2003). Natural occurrence of metallothionein-like proteins in the liver of fish Oreochromis niloticus and effects of cadmium, lead, copper, zinc, and iron exposures on their profiles. Bull. Environ. Contam. Toxicol. 70, 619-627.

Barham, D. and Trinder, P. (1972). Enzymatic determination of uric acid. Analyzed, 97:142-145.

Belal, I. E. H. and Assem, H. (2011). Pharmacological mechanisms of diazepam in fish I. J Environ Sci. Eng., 5: 453-459.

Da Cuna, R.H.; Rey Vazquez, G.; Piol, M.N,; Guerrero, N. V.; Maggese, M.C. and Lo Nostro, F.L. (2011). Assessment of the acute toxicity of the organochlorine pesticide endosulfan in Cichlasoma dimerus (Teleostei,Perciformes). Ecotoxicol Environ. Saf., 74:1065-1073.

Dautremepuits, C.; Paris-Palacios, S.; Betoulle, S. and Vernet, G. (2004). Modulation in hepatic and head kidney parameters of carp (Cyprinus carpio L.) induced by copper and chitosan. Comp. Biochem. Physiol. C. Toxicol. Pharmacol, 137: 325-333.

Drabkin, D. L. and Austin, J. H. (1932). Spectrophotometric studies: spectrophotometric constants for common haemoglobin derivatives in human, dog and rabbit blood. J Biol. Chem, 98: 719-733.

El-Bagori, H. M. (2001). Pathological studies on some environmental pollution on some freshwater fish in Sharkia Governorate. M. V. Sc. Thesis, Faculty of Veterinary Medicine, Zagazig University, Zagazig, Egypt.

El-Boshy, M.E.S.; Gadalla1, H. A. and Abd El-Hamied, F.M. (2014). Immunological, hematological and biochemical changes induced by short term exposure to cadmium in catfish (Clarias gariepinus). J Coastal Life Med., 2(3): 175-180.

Ellman, G.L.; Courtney, K.D.; Andreas, V.J. and Featherstone, R.M. (1961). A new and rapid colorimetric determination of acetylcholinesterase activity. Biochem. Pharmacol., 7: 88-95.

El-Sayed, A. F.M. (2006). Tilapia Culture. CAB International Publishers,UK, p. 277.

Fawcett, J. K. and Scott, J.E. (1960). A rapid and precise methods for the determination of urea. J Clin Pathol., 13:156-159.

Fiske, E. H. and Subbarow, Y.V. (1925). The colorimetric determination of phosphorus. Biol Chem., 66:375- 400.

Gheju, M. (2011). Hexavalent Chromium Reduction with Zero-Valent Iron (ZVI) in Aquatic Systems. Water, Air, Soil Pollut., 222: 103-148.

Gholami-Seyedkolaei S.J.; Mirvaghefi A.; Farahmand H. and Kosari A. A. (2013). Effect of a glyphosate-based herbicide in Cyprinus carpio: assessment of acetylcholin-esterase activity, hematological responses and serum biochemical parameters. Ecotoxicol Environ Saf., 98:135-141.

Guzmán-Guillén, R., Manzano, I. L., Morenoa, I. M., Ortega, A. I. P., Moyano, R., Blanco, A. and Cameán, A. M. (2015). Cylindrospermopsin induces neurotoxicity in tilapia fish (Oreochromis niloticus) exposed to Aphanizomenon ovalisporumRemedios. Aquatic Toxicol., 161:17-24.

Hassan, B.; El-Salhia, M.; Khalifa, A.; Assem, H.; Al Basomy, A. and El- Sayed, M. (2013). Invironmental isotonicity improves cold tolerance of Nile tilapia, Oreochromis niloticus, in Egypt. Egypt J. Aquat. Res., 39: 59-65. 
Heath, A.G. (1995). Water Pollution and Fish Physiology. CRC. Press. Inc. Boca Raton, Florida. p.359.

Hegazi, M.M.; Mostafa, A. H.; Assem, E. H.; Mourad, H. M. and Hasanein S. S. (2015). The effect of seasonal metal pollution in two hotspots (El- Mex, AbuQir) Bays on ATPases in gills of Siganus rivulatus Int J Environ Monitor. Analysis. In Press.

Ibrahim, A. Th. and Omar, H. M. (2013). Seasonal variation of heavy metals accumulation in muscles of the African Catfish Clarias gariepinus and in River Nile water and sediments at Assiut Governorate, Egypt. J. Biol. Earth. Sci.; 3(2): B236-B248.

Kori- Siakpere O. (2008). Effects of sublethal concentrations of potassium permanganate on nitrogenous waste products of African catfish: Clarias gariepinus (Burchell, 1822).Inter. J Integrat. Biol., 4(1): 41-44

Lionetto M.G.; Caricato R.; Calisi A.; Giordano ME. and Schettino T. (2013). Acetylcholinesterase as a Biomarker in environmental and occupational medicine: new insights and future perespectives. Biomed Res Int. Article ID 321213, 8 pages

Li, Z.H.; Li, P.; Dzyuba, B. and Randak, T. (2010). Influence of environmental related concentrations of heavy metals on motility parameters and antioxidant responses in sturgeon sperm. Chem Biol. Interact., 188: 473-477.

Linde, A. R., and Vazquez, E. G. (2006). A Simple Assay to Quantify Metallothionein Helps to Learn about Bioindicators and Environmental Health. Biochem Molec. Biol. Education., 34(5): 360-363.

Lowry, O.H.; Rosebrough, N.J.; Farr, A. L. and Randall, R. J. (1951). Protein measurement with the Folin phenol reagent. J Biol. Chem., 193: 265- 275.

Masoud, M. S.; Elewa, A. A.; Ali, A. E. and Mohamed, E. A. (2005). Distribution of some metal concentrations in water and sediments of Lake Edku, Egypt. Bulletin of the Chemists and Technologists of Macedonia, 24(1): 21-34.

McDonald, M. D., Grosell, M., (2006). Maintaining osmotic balance with an aglomerular kidney. Comp Biochem Physiol., 143(C): 447- 458.

Mishra, A.K. and Mohanty, B. (2009). Effect of hexavalent chromium exposure on the pituitary-interrenal axis of a teleost, Channa punctatus (Bloch). Chemosphere 76: 982-988.

Öner, M., Atli, G. and Canli, M. (2008). Changes in serum biochemical parameters of freshwater fish Oreochromis niloticus following prolonged metal $(\mathrm{Ag}, \mathrm{Cd}, \mathrm{Cr}$, $\mathrm{Cu}$, and $\mathrm{Zn}$ ) exposures. Environ Toxicol Chem., 27: 360-366.

Osman, A. G. M. and Kloas, W. (2010). "Water Quality and Heavy Metal Monitoring in Water, Sediments and Tissues of the African Catfish Clarias gariepinus (Burchell, 1822) from the River Nile, Egypt," J Environ Protect, Vol. 1, pp. 389-400. doi:10.4236/jep.2010.14045

Praveena, M.; Sandeep, V.; Kavitha, N. and Jayantha, Rao K. (2013). Impact of Tannery Effluent, Chromium on Hematological Parameters in a Fresh Water Fish, Labeo Rohita (Hamilton). Res J Animal, Veterinary and Fishery Sci., 1(6): $1-5$.

SAS Institute Inc. (2004). SAS/ SHARE ${ }^{\circledR} 9.1$ User's Guide. SAS Institute Inc., Cary, N C, 27513, USA.

Shah, S.L. and Altindag, A. (2005). Alterations in the immunological parameters of tench (Tinca tinca L.) after acute and chronic exposure to lethal and sublethal mercury treatments. Bull Environ. Contam Toxicol., 73: 911 - 918. 
Shalaby, A.M. (2001). Protective effect of Ascorbic acid against Mercury intoxication in Nile tilapia (Oreochromis niloticus), J. Egypt Acad. Soc. Environ Develop (D Environmental studies) 2(3):79 - 97.

Shi, H.; Sui, Y.; Wang, X.; Luo, Y. and Ji, L. (2005). Hydroxyl radical production and oxidative damage induced by cadmium and naphthalene in liver of Carassius auratus. Comp. Biochem. Physiol. C. Toxicol Pharm., 140(1): 115-121.

Trinder, P. (1969). Determination of glucose concentration in blood using glucose oxidase with an alternative oxygen receptor. Ann Clin Biochem, 6: 24-27.

Vaseem, H. and Banerjee, T.K. (2012). Toxicity analysis of effluent released during recovery of metals from Polmetallic Sea nodules using fish hematological parameters. The functioning of Ecosystems, Prof. Mahamane Ali (ed.), 249260, ISBN: 978-953-51-0573-2, In Tech.

Vutukuru, S.S.; Prabhath, N.A.; Raghavender M. and Yerramilli, A. (2007). Effect of arsenic and chromium on the serum amino-transferases activity in Indian major carp, Labeo rohita. Int J Environ Res Public Health, 4(3):224-227.

Witeska, M. and Kosciuk, B. (2003). Changes in common carp blood after short-term zinc exposure. Environ Sci Pollut Res., 3:15 - 24.

$\mathrm{Xu}$, W.; Jilong, L.; Houjuan, X. and Shiwen, X. (2011). Review of toxicology of atrazine and chlorpyrifos on fish. J. North Agric. Univ., 18(4):88-92.

Zaghloul, K. H.; Hasheesh, W. S.; Zahran, I. A. and Marie, M. A. (2007). Ecological and biological studies on the Nile tilapia Oreochromis niloticus along different sites of Lake Burulus. Egypt J Aquat Biol \& Fish. Vol. 11, No.3: 57-88.

Zaki, M. S.; Authman, M. M. N.; Hammam, A. M. M. and Shalaby, S. I. (2014). Aquatic Environmental Pollution in the Egyptian Countryside and Its Effect on Fish Production (Review). Life Sci. J., 11(9).

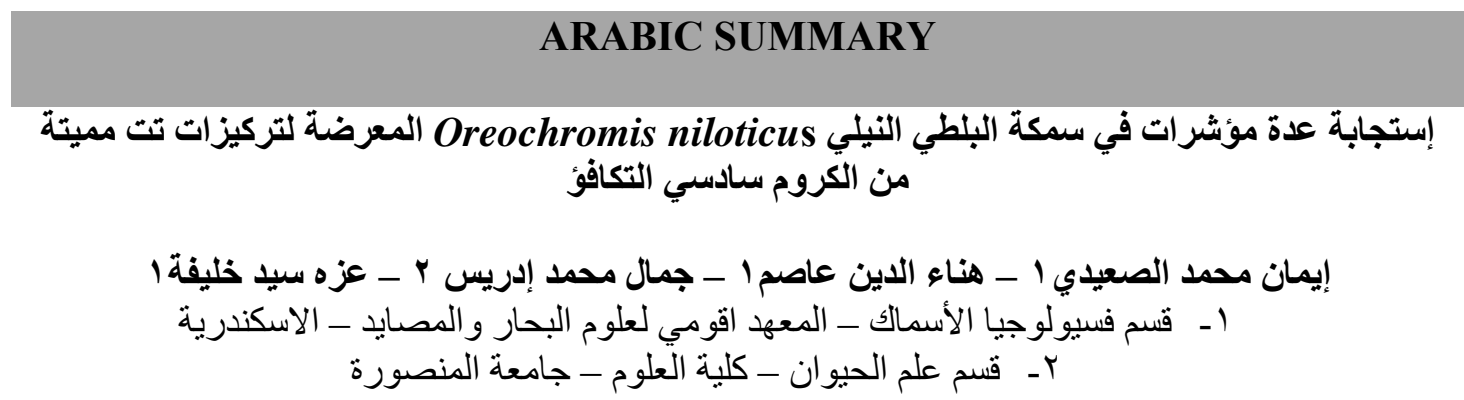

دُرسن تأثير تعرض أسماك البلطي النيلي Oreochromis niloticus لتركيزين أقل من التركيز القاتل من الكروم

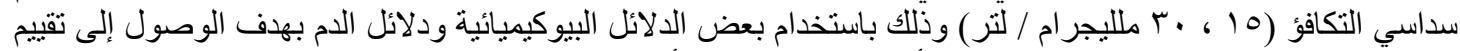

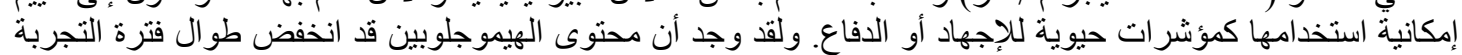

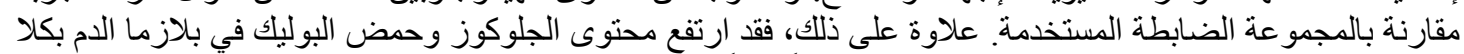

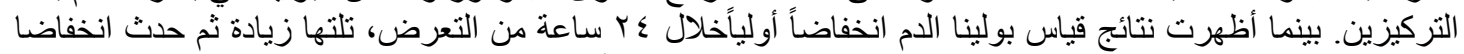

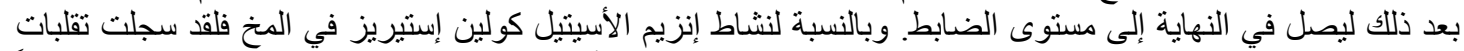

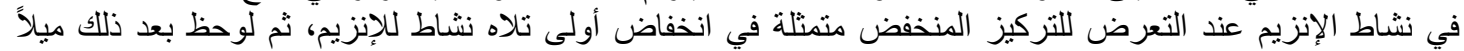

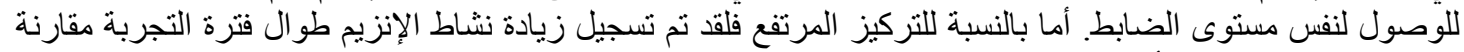

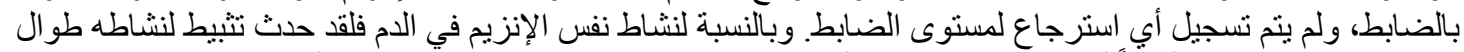

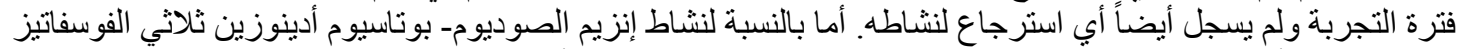

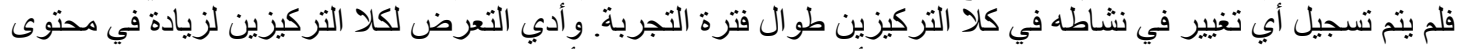

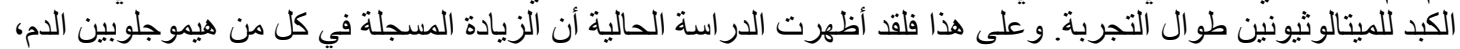

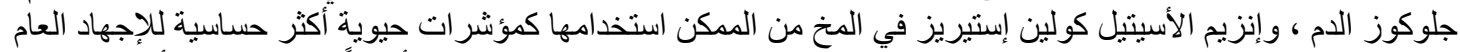

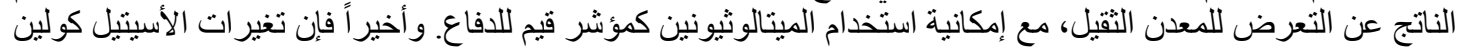

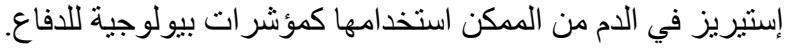

